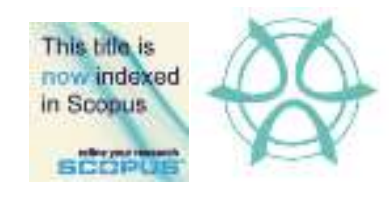

PLANNING MALAYSIA:

Journal of the Malaysian Institute of Planners

VOLUME 18 ISSUE 4 (2020), Page 340 - 351

\section{RISK FACTORS TOWARDS PUBLIC-PRIVATE PARTNERSHIPS (PPP) PROJECTS IMPLEMENTING BUILDING INFORMATION MODELLING (BIM) IN THE UNITED KINGDOM (UK): A LESSON LEARNT FOR MALAYSIA}

\author{
Siti Nora Haryati Abdullah Habib ${ }^{1}$, Syuhaida Ismail ${ }^{2}$, Sharifah Mazlina \\ Syed Khuzzan ${ }^{3}$ \\ ${ }^{1,3}$ Kulliyyah of Architecture and Environmental Design \\ INTERNATIONAL ISLAMIC UNIVERSITY MALAYSIA \\ ${ }^{2}$ Razak Faculty of Technology and Informatics \\ UNIVERSITI TEKNOLOGI MALAYSIA
}

\begin{abstract}
Public Private Partnership (PPP) projects involve stakeholders engaged in various contract structures in a lengthy contract duration. Such situations expose the projects to risks related to collaborative working and information integration. Building Information Modelling (BIM) is seen as a mechanism to improve the collaboration and integration in the PPP projects. However, BIM also exposes its users to additional risk when the barriers in sharing information are reduced. Therefore, the aim of this paper is to investigate the BIM risk factors that have significant impact towards PPP projects implementing BIM. Since the United Kingdom (UK) is considered advanced in practising PPP and BIM, this study investigates the UK industry players' views on what they considered as significant BIM factors in PPP projects. Consequently, the study has identified six (6) most significant BIM risk factors through questionnaire and experts' interviews. The findings provide a lesson learnt for Malaysia to consider the BIM risks in implementing BIM in PPP projects.
\end{abstract}

Keywords: Building Information Modelling, Public Private Partnership, Risk Factors, Construction Procurement

\footnotetext{
${ }^{1}$ Assistant Professor at International Islamic University Malaysia. Email: ctnora@iium.edu.my
} 
PLANNING MALAYSIA

Journal of the Malaysia Institute of Planners (2020)

\section{INTRODUCTION}

Public Private Partnership (PPP) is a strategic approach for a government to provide public infrastructure and services to the public users by using private sector resources and expertise. PPP is either it uses private finance to reduce the financial burden of the government, or both the public and private entities sharing the financial investment in the PPP project with the aim to deliver better products or services to the users, thus providing more value for money (Hodge and Greve, 2007; Khanom, 2010). The concept of PPP was introduced in the United Kingdom (UK) since 1970s (Gamble, 1988) however in Malaysia, PPP scheme started since 1980s through privatisation followed by Private Finance Initiative (PFI) in later years (Abdul Rashid, 2007). Through PPP, Malaysia has able to procure projects such as Teaching Hospital for IIUM Kuantan, Second Penang Bridge, West-Coast Highway and Damansara-Ulu Kelang Expressway (DUKE). In addition, 24 government projects worth RM5.2 billion under Budget 2019 are to be procured via PPP whilst another RM50 million allocated in Budget 2020 to stimulate PPP in the construction industry (BNM, 2019a, 2019b).

Even though PPP is a great alternative for the government to benefit public users, the facts that PPP normally entails with lengthy contract duration involving a myriad of parties and affecting the interest of public users have exposed PPP to many risks (Li, Akintoye, Edwards, and Hardcastle, 2005; Ismail \& Harris, 2014). The emergence of Building Information Modelling (BIM) in the construction industry is an immense phenomenon that can potentially assist the industry players to mitigate risks in PPP projects (Lehtinen, 2012; Ganah \& John, 2013; Ren \& Li, 2017). BIM has the capability in facilitating information sharing and data integration in three-dimensional (3D) data-rich digital platform while offering for a more collaborative and integrative working environment that well-suites to the nature of PPP. Notwithstanding such potentials, the risks associated with BIM are also myriad and inevitable. Thus, based on the UK's experience which considered among the pioneers and advanced in implementing PPP and BIM, the present study is conducted to investigate the significant BIM risk factors that can potentially impact PPP projects. The outcome of the study is considered relevant as a lesson for Malaysia in taking measures to ensure the success of PPP projects implementing BIM.

\section{RESEARCH BACKGROUND}

For almost thirty years, Private Finance Initiative (PFI) has become the most Public Private Partnership (PPP) variant that being used in the United Kingdom (UK), which is later in 2012 has been reformed to Private Finance 2 (PF2) to make it 'less private' as alternative to the original PFI. Despite the evolution, both PFI and PF2 remain as a collaborative contracting method for the public and private entities to work together in delivering public infrastructure and services. 
Siti Nora Haryati Abdulllah Habib, Syuhaida Ismail, Sharifah Mazlina Syed Khuzzan,

Identification of Significant BIM Risk Factors for PPP Projects Implementing BIM in the UK: A Lesson

Learnt for Malaysia

The characteristics of PPP include 'bundling' contract, which is the combination of the design, construction, finance, operation and maintenance of the facility contracted out to a private consortium. It involves complex contractual structures, myriad of parties with different roles and interest that need to sustain for 20 to 40 years contract duration (Eaton \& Akbiyikli, 2009; Athias \& Saussier, 2010). Figure 1 shows the typical contractual structures in PPP projects.

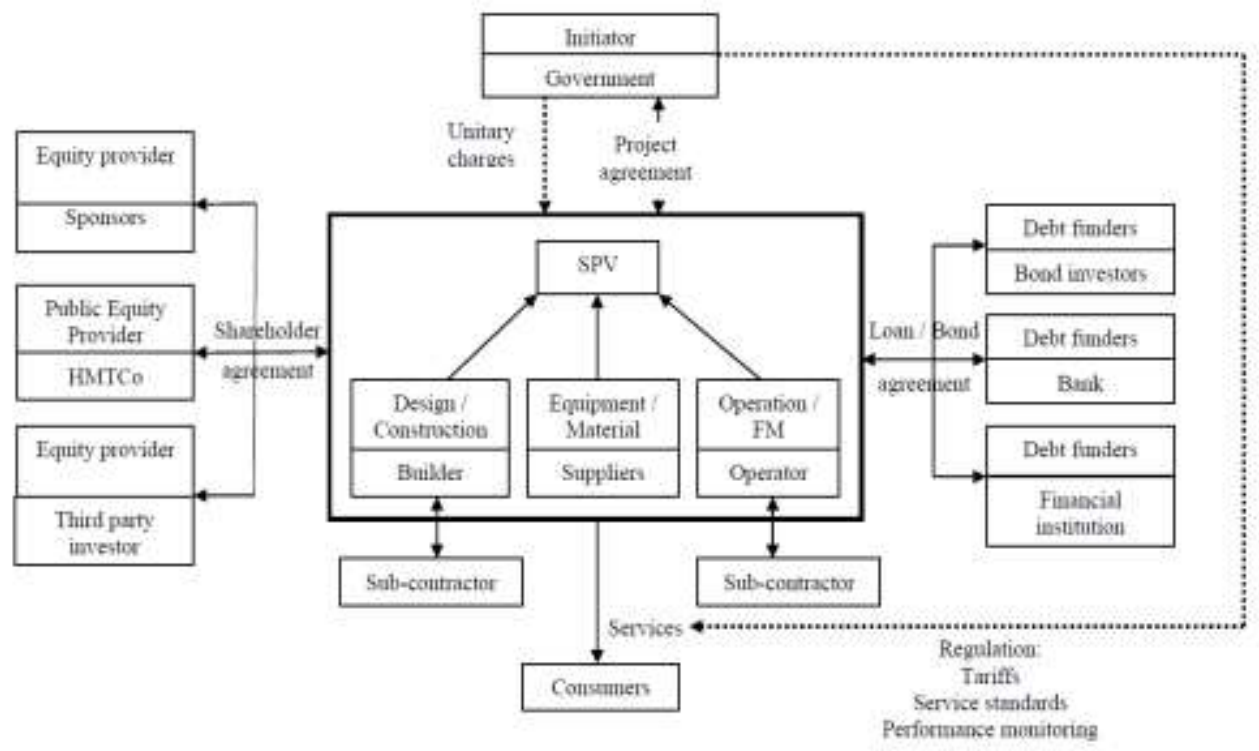

Figure 1: Typical contractual structures in PPP project Source: Sundaraj (2012)

The complexity of PPP structures leading to the exposure of risks mostly related to the collaborative arrangement, unpredictable future changes and demands; and the expectations on the ability to deliver the project and services with value for money. Therefore, procuring public infrastructure and services via PPP is not always successful (Soomro \& Zhang, 2015). Despite the fame of PPP, critics and issues surrounding PPP also being voiced, mostly regarding the real fact of value of money which PPP is supposed to offer (Pollock et al,, 2007; Shaoul, 2009); public accountability issue related to public expenditure and changes in risk allocations (Price \& Pollock, 2008; Asenova \& Beck, 2009); and profiteering by the shareholders (Chinyio \& Gamesan, 2009).

Therefore, some scholars encourage the use of BIM in PPP projects to mitigate the risks (Laishram, 2013; Quinn, 2014; Ren \& Li, 2017). BIM is defined as "a modelling technology and associated set of processes to produce, communicate, analyse and use of digital information models throughout construction project life- 
cycle" (CIDB, 2016, p.3). Even though it is not expected to completely overcome the uncertainty and complexity of the PPP projects, BIM may encourage the parties to closely collaborate and integrate as well as facilitate possible changes that might happen during the course of the project life span. Impact on future costs and other possible constraints can also be projected which can improve the financial viability. Furthermore, BIM can potentially aid in forecasting and appraising value for money, hence excessive profiteering by the shareholders can be avoided.

St Helens and Knowsley Hospital Project delivered three months ahead of the original schedule is one example of a PFI-BIM project that confirmed the benefits of BIM in PPP projects. Although the adjacent hospitals' buildings need to stay operational throughout the construction period, coordination through BIM enabled offsite construction to be carried out with waste reduction, $60-70 \%$ time savings to find documents and $75-80 \%$ savings in design coordination (BuildingSMART, 2010). Another PFI-BIM project, £1 billion Barts and Royal London Hospitals Project, also experienced $10 \%$ cost reduction via design coordination, construction monitoring and planning (Harty, Throssell, Jeffrey \& Stagg, 2010). Notwithstanding such potentials, the risks associated with BIM is inevitable, where 24 risk factors were identified as presented in Table 1.

Table 1: BIM risk factors

\begin{tabular}{|c|c|c|c|c|c|c|c|c|}
\hline \multirow{2}{*}{$\begin{array}{l}\text { Risk } \\
\text { Level }\end{array}$} & \multirow{2}{*}{ Risk Subgroup } & \multirow{2}{*}{ Risk Factors } & \multicolumn{6}{|c|}{ Authors } \\
\hline & & & $\mathbf{A}$ & B & $\mathbf{C}$ & D & $\mathbf{E}$ & $\mathbf{F}$ \\
\hline \multirow[t]{5}{*}{ Macro } & \multirow[t]{2}{*}{ Social } & \multirow{2}{*}{$\begin{array}{l}\text { Resistance to change } \\
\text { Lack of available skilled personnel }\end{array}$} & & & & & $\checkmark$ & \\
\hline & & & & & $\checkmark$ & & $\checkmark$ & \\
\hline & Legal & $\begin{array}{l}\text { Existing legal system poorly equipped to regulate } \\
\text { multiparty, collaborative relationship }\end{array}$ & & $\checkmark$ & & & & \\
\hline & \multirow{2}{*}{$\begin{array}{l}\text { Political } \\
\text { Technological }\end{array}$} & Change of BIM policies & $\checkmark$ & & & & & \\
\hline & & Lack of BIM standards and guidelines & & & $\checkmark$ & & $\checkmark$ & \\
\hline \multirow[t]{12}{*}{ Meso } & \multirow[t]{10}{*}{ Contractual } & Liability issues & $\checkmark$ & & & & $\checkmark$ & $\checkmark$ \\
\hline & & Ownership of information / model & $\checkmark$ & & & $\checkmark$ & $\checkmark$ & \\
\hline & & Status of BIM model & $\checkmark$ & & & & $\checkmark$ & \\
\hline & & $\begin{array}{l}\text { Unclear position, duty, responsibility, and liability } \\
\text { of Information Manager }\end{array}$ & $\checkmark$ & & & $\checkmark$ & $\checkmark$ & $\checkmark$ \\
\hline & & \multirow{2}{*}{$\begin{array}{l}\text { Lack of guidelines for contractual agreements } \\
\text { Intellectual property rights }\end{array}$} & $\checkmark$ & & & & $\checkmark$ & \\
\hline & & & & & & & & $\checkmark$ \\
\hline & & Unclear allocation of risks & & & & $\checkmark$ & $\checkmark$ & \\
\hline & & Privity of contract and third-party reliance & & & & $\checkmark$ & $\checkmark$ & $\checkmark$ \\
\hline & & Integrity of BIM model & & & & $\checkmark$ & & $\checkmark$ \\
\hline & & Data security & & & & & $\checkmark$ & $\checkmark$ \\
\hline & \multirow[t]{2}{*}{ Financial } & \multirow{2}{*}{ High initial cost to implement } & $\checkmark$ & & $\checkmark$ & & $\checkmark$ & \\
\hline & & & $\checkmark$ & & & & $\checkmark$ & \\
\hline \multirow[t]{7}{*}{ Micro } & \multirow[t]{3}{*}{ Process } & Increase short-term workload & & & $\checkmark$ & & & \\
\hline & & \multirow{2}{*}{$\begin{array}{l}\text { Lack of collaborative work processes } \\
\text { Inadeguate top management commitment }\end{array}$} & & & & & $\checkmark$ & \\
\hline & & & & & $\checkmark$ & & & \\
\hline & \multirow[t]{4}{*}{ Technical } & \multirow{4}{*}{$\begin{array}{l}\text { Defective integration between software tools/ } \\
\text { Interoperability not guaranteed } \\
\text { Errors in the model } \\
\text { Little knowledge and experience } \\
\text { Model management difficulties }\end{array}$} & $\checkmark$ & & $\checkmark$ & & $\checkmark$ & \\
\hline & & & $\checkmark$ & $\checkmark$ & & & $\checkmark$ & \\
\hline & & & $\checkmark$ & & $\checkmark$ & & & \\
\hline & & & $\checkmark$ & & $\checkmark$ & & & \\
\hline \multicolumn{9}{|c|}{ References: } \\
\hline $\mathrm{A}=\mathrm{Tal}$ & i (2014) & $\mathrm{D}=$ Simonian and $\mathrm{Ko}$ & nan & 010 & & & & \\
\hline $\mathrm{B}=\mathrm{Nes}$ & (2011) & $\mathrm{E}=$ Azhar et al. $(2012$ & & & & & & \\
\hline $\mathrm{C}=\mathrm{Chi}$ & , Wu, and Huang (2 & $\mathrm{F}=$ Boyes $(2014$ & & & & & & \\
\hline
\end{tabular}


Siti Nora Haryati Abdulllah Habib, Syuhaida Ismail, Sharifah Mazlina Syed Khuzzan,

Identification of Significant BIM Risk Factors for PPP Projects Implementing BIM in the UK: A Lesson

Learnt for Malaysia

\section{RESEARCH METHODOLOGY}

Survey research with structured questionnaire and semi-structured validation were carried out to investigate the BIM risks factors that have significant impact on PPP projects based on "significance" 5-Likert scale. Due to the absence of database on the number PPP projects implementing BIM in the UK, convenient sampling of organisations and persons involved in PPP and BIM projects and research was employed, where 700 questionnaires were distributed to 128 organisations and 60 academicians. A total of 88 valid questionnaires were used representing $12.57 \%$ response rate. The low response rate is anticipated as BIM is considered new in the construction industry. This is also due to some of the companies have a policy of prohibiting participation in any surveys or questionnaires received from external sources. The respondents were divided in three categories as shown in Table 2.

Table 2: The categories of the respondents

\begin{tabular}{lcc}
\hline \multicolumn{1}{c}{ Categories of the Respondents } & Frequency & Percentage \\
\hline & & \\
Involve in PPP projects only & 10 & 11.4 \\
Involve in PPP and BIM projects & 44 & 51.1 \\
Involve in BIM projects only & 34 & 37.5 \\
Total & 88 & 100.0 \\
\hline
\end{tabular}

The data collected were analysed using the Statistical Package for Social Sciences (SPSS) V23 to calculate the mean score and mean score ranking to obtain the relative significance of each factor for PPP projects implementing BIM. The differences in the opinion among the three groups of respondents were then investigated via Kruskal-Wallis $\mathrm{H}$ test and subsequently followed by MannWhitney $\mathrm{U}$ test for pairwise testing.

\section{RESEARCH FINDINGS AND DISCUSSION Demographic data of the respondents}

Despite the low response rate, the number was considered appropriate for the study since $70 \%$ of the questionnaires were answered by a very experienced and knowledgeable group with more than 10 years of experience in the construction industry. Figure 2 presents the demographic data of the respondents. 
PLANNING MALAYSIA

Journal of the Malaysia Institute of Planners (2020)

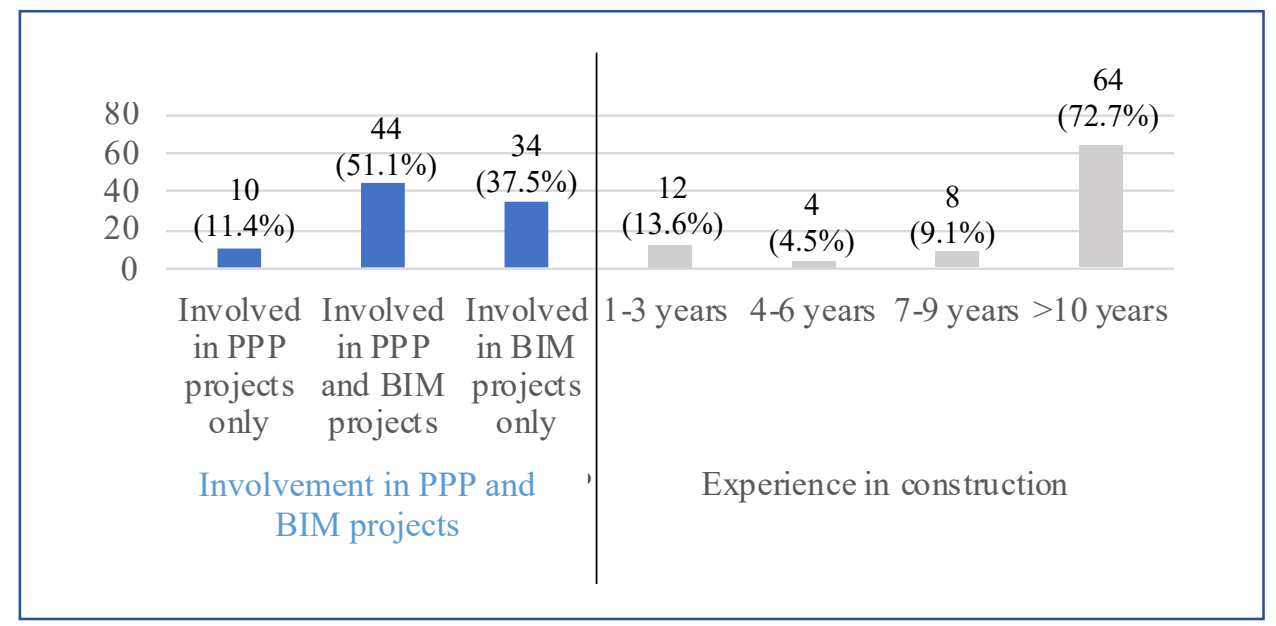

Figure 2: Demographic data of the respondents

\section{Results and Discussion}

Table 3 shows the mean ranking based on the opinions of the respondents on the significance of BIM risk factors on PPP projects. Risk factors with mean values over 4.00 are regarded as the most significant risk factors and in this case, there are two most significant risk factors, which are "lack of available skilled personnel" and "resistance to change". On the other hand, risk factors which scored mean values of less than 3.50 are considered as moderate risk factors. Subsequently, the data were analysed using Kruskal-Wallis $\mathrm{H}$ test to evaluate the differences of opinions among the three categories of respondents. The categories were coded with 1, 2 and 3 respectively. 
Siti Nora Haryati Abdulllah Habib, Syuhaida Ismail, Sharifah Mazlina Syed Khuzzan,

Identification of Significant BIM Risk Factors for PPP Projects Implementing BIM in the UK: A Lesson

Learnt for Malaysia

Table 3: Respondents' opinions on the significance of BIM risk factors on PPP projects

\begin{tabular}{|c|c|c|c|c|c|c|c|c|c|}
\hline \multirow[t]{2}{*}{ No } & \multirow[t]{2}{*}{$\begin{array}{l}\text { BIM risk } \\
\text { factors }\end{array}$} & \multicolumn{2}{|c|}{$\begin{array}{c}\text { PPP } \\
\text { projects } \\
\text { only }\end{array}$} & \multicolumn{2}{|c|}{$\begin{array}{l}\text { PPP + BIM } \\
\text { projects }\end{array}$} & \multicolumn{2}{|c|}{$\begin{array}{c}\text { BIM } \\
\text { projects } \\
\text { only }\end{array}$} & \multicolumn{2}{|c|}{ Overall } \\
\hline & & Mean & Rank & Mean & Rank & Mean & Rank & Mean & Rank \\
\hline 1 & $\begin{array}{l}\text { Lack of available skilled personnel } \\
\text { Resistance to change }\end{array}$ & 4.20 & 2 & 4.20 & 1 & 4.18 & 2 & 4.20 & 1 \\
\hline 2 & Little knowledge and experience & 3.60 & 4 & 4.11 & 2 & 4.30 & 1 & 4.13 & 2 \\
\hline 3 & $\begin{array}{l}\text { Lack of collaborative work } \\
\text { processes }\end{array}$ & 3.50 & 9 & 4.02 & 4 & 4.00 & 8 & 3.95 & 3 \\
\hline 4 & $\begin{array}{l}\text { Integrity of BIM model } \\
\text { Defective integration between }\end{array}$ & 4.40 & 1 & 3.89 & 7 & 3.88 & 11 & 3.94 & 4 \\
\hline 5 & software tools & 3.80 & 3 & 3.91 & 6 & 4.03 & 6 & 3.94 & 5 \\
\hline 6 & $\begin{array}{l}\text { Inadequate top management } \\
\text { commitment }\end{array}$ & 3.00 & 18 & 4.02 & 3 & 3.88 & 12 & 3.85 & 6 \\
\hline 7 & $\begin{array}{l}\text { Ownership of BIM model } \\
\text { High initial cost to implement }\end{array}$ & 3.40 & 11 & 4.02 & 5 & 3.76 & 18 & 3.85 & 7 \\
\hline 8 & Lack of BIM standards and guidelit & 3.00 & 19 & 3.70 & 10 & 4.06 & 4 & 3.76 & 8 \\
\hline 9 & Liability issues & 3.20 & 14 & 3.73 & 9 & 3.91 & 9 & 3.74 & 9 \\
\hline 10 & Data security & 3.60 & 6 & 3.52 & 17 & 4.00 & 7 & 3.71 & 10 \\
\hline 11 & $\begin{array}{l}\text { Existing legal system not equipped } \\
\text { support BIM }\end{array}$ & 2.60 & 24 & 3.57 & 12 & 4.18 & 3 & 3.69 & 11 \\
\hline 12 & Lack of guidelines for & 3.40 & 10 & 3.57 & 14 & 3.88 & 10 & 3.67 & 12 \\
\hline 13 & $\begin{array}{l}\text { contractual agreement } \\
\text { Model management difficulties }\end{array}$ & 3.60 & 5 & 3.55 & 15 & 3.79 & 16 & 3.64 & 13 \\
\hline 14 & $\begin{array}{l}\text { Time consuming to be } \\
\text { proficient }\end{array}$ & 3.40 & 12 & 3.55 & 16 & 3.85 & 14 & 3.64 & 14 \\
\hline 15 & Status of BIM model & 3.00 & 17 & 3.73 & 8 & 3.67 & 19 & 3.62 & 15 \\
\hline 16 & $\begin{array}{l}\text { Unclear position, duty, responsibili1 } \\
\text { and liability of Information Ma }\end{array}$ & 3.20 & 15 & 3.34 & 20 & 4.00 & 5 & 3.60 & 16 \\
\hline 17 & Unclear allocation of risks & 3.60 & 8 & 3.36 & 19 & 3.85 & 13 & 3.57 & 17 \\
\hline 18 & $\begin{array}{l}\text { Errors in the model } \\
\text { Increase short term work-load } \\
\text { Change of BIM policies }\end{array}$ & 2.80 & 23 & 3.59 & 11 & 3.67 & 21 & 3.53 & 18 \\
\hline 19 & Privity of contract and thir & 3.00 & 21 & 3.57 & 13 & 3.52 & 23 & 3.48 & 19 \\
\hline 20 & party reliance & 3.60 & 7 & 3.50 & 18 & 3.42 & 24 & 3.48 & 20 \\
\hline 21 & Intellectual property rights & 3.20 & 13 & 3.20 & 21 & 3.82 & 15 & 3.44 & 21 \\
\hline 22 & & 3.00 & 16 & 3.18 & 22 & 3.79 & 17 & 3.39 & 22 \\
\hline 23 & & 2.80 & 22 & 3.16 & 23 & 3.55 & 22 & 3.26 & 23 \\
\hline 24 & & 3.00 & 20 & 3.00 & 24 & 3.67 & 20 & 3.25 & 24 \\
\hline
\end{tabular}

As seen in Table 4, Kruskal-Wallis $\mathrm{H}$ test revealed that six risk factors showed significant values of less than 0.05 . The low significance values indicate that the opinions of the three groups of respondents regarding the significance of BIM risks towards PPP projects vary significantly. The data were then underwent Mann-Whitney $U$ test in order to test pairwise differences of opinions among the three groups. The values which are statistically significant are marked in bold; 
(Asymptotic Significance is less than 0.015 . This provides that the opinions between the groups of respondents when being compared vary significantly.

Table 4: Difference of opinion of the respondents on the significance of the BIM risk factors on PPP projects

\begin{tabular}{lcccc}
\hline \multirow{2}{*}{ Risks factors } & $\begin{array}{c}\text { Kruskal- } \\
\text { Wallis H }\end{array}$ & \multicolumn{3}{c}{$\begin{array}{c}\text { Mann-Whitney U } \\
\text { (at sig. 0.015) }\end{array}$} \\
\cline { 2 - 5 } & Sig. & \multicolumn{3}{c}{$\begin{array}{c}\text { Respondents' } \\
\text { category }\end{array}$} \\
\cline { 3 - 5 } & & $\mathbf{1 \& 2}$ & $\mathbf{1 \& 3}$ & $\mathbf{2 \& 3}$ \\
\hline Defective integration between software tools & 0.037 & $\mathbf{0 . 0 1 1}$ & 0.037 & 0.511 \\
\hline Liability issues & 0.000 & 0.053 & $\mathbf{0 . 0 0 1}$ & $\mathbf{0 . 0 0 1}$ \\
\hline Time consuming to be proficient & 0.004 & 0.962 & $\mathbf{0 . 0 0 2}$ & $\mathbf{0 . 0 0 1}$ \\
\hline Increase short term work-load & 0.029 & 0.560 & 0.218 & $\mathbf{0 . 0 0 8}$ \\
\hline Change of BIM policies & 0.005 & 0.849 & 0.046 & $\mathbf{0 . 0 0 2}$ \\
\hline Intellectual property rights issue & 0.014 & 0.782 & 0.601 & $\mathbf{0 . 0 0 2}$ \\
\hline
\end{tabular}

Based on the responses received from the survey, eighteen (18) BIM risk factors considered to have significant impact to PPP projects were identified (overall mean score above 3.50). Since respondents' opinions vary significantly, validation with six industry experts was undertaken as shown in Table 4.

Table 4: Experts' background

\begin{tabular}{cccccc}
\hline Experts & Designation & $\begin{array}{c}\text { Work } \\
\text { background }\end{array}$ & $\begin{array}{c}\text { Years of } \\
\text { experience }\end{array}$ & $\begin{array}{c}\text { Experience in } \\
\text { PPP projects }\end{array}$ & $\begin{array}{c}\text { Experience in } \\
\text { BIM projects }\end{array}$ \\
\hline IV-1 & Director & $\begin{array}{c}\text { Construction } \\
\text { Lawyer }\end{array}$ & 21 years & $\begin{array}{c}12 \text { years as legal } \\
\text { advisor }\end{array}$ & $\begin{array}{c}5 \text { years in } \\
\text { research on BIM }\end{array}$ \\
\hline IV-2 & $\begin{array}{c}\text { Chief } \\
\text { Executive; } \\
\text { Professor }\end{array}$ & $\begin{array}{c}\text { Construction } \\
\text { Lawyer; } \\
\text { Academician }\end{array}$ & 26 years & $\begin{array}{c}25 \text { years as legal } \\
\text { advisor }\end{array}$ & $\begin{array}{c}6 \text { years in } \\
\text { research on BIM }\end{array}$ \\
\hline IV-3 & Director & $\begin{array}{c}\text { Construction } \\
\text { Lawyer }\end{array}$ & 30 years & $\begin{array}{c}15 \text { years as legal } \\
\text { advisor }\end{array}$ & $\begin{array}{c}4 \text { years as legal } \\
\text { advisor }\end{array}$ \\
\hline IV-4 & $\begin{array}{c}\text { Senior } \\
\text { Lecturer }\end{array}$ & $\begin{array}{c}\text { Construction } \\
\text { Lawyer; } \\
\text { Academician }\end{array}$ & 11 years & $\begin{array}{c}2 \text { years as legal } \\
\text { advisor }\end{array}$ & $\begin{array}{c}5 \text { years in } \\
\text { research on BIM }\end{array}$ \\
\hline IV-5 & $\begin{array}{c}\text { SPV and } \\
\text { Investment } \\
\text { Manager }\end{array}$ & $\begin{array}{c}\text { Survity } \\
\text { Project } \\
\text { Manager }\end{array}$ & 22 years & 15 years & $\begin{array}{c}5 \text { years use BIM } \\
\text { in design and } \\
\text { data }\end{array}$ \\
\hline IV-6 & $\begin{array}{c}\text { Quantity } \\
\text { Surveyor }\end{array}$ & $\begin{array}{c}\text { Surveyor, } \\
\text { Developer }\end{array}$ & 17 years & 17 years & 7 years \\
\hline
\end{tabular}


Siti Nora Haryati Abdulllah Habib, Syuhaida Ismail, Sharifah Mazlina Syed Khuzzan,

Identification of Significant BIM Risk Factors for PPP Projects Implementing BIM in the UK: A Lesson

Learnt for Malaysia

Two of the BIM risks factors, which are lack of available skilled personnel' and 'resistance to change' are social-related risk due to unfamiliarity with the new norms of working with collaborative and integrative BIM (Arayici, Egbu, \& Coates, 2012; Lindblad \& Vass, 2015). These are also the reasons of technical competency-related risks which are 'little knowledge and experience'; and 'model management difficulties', listed as significant BIM risks to PPP projects. Khosrowshahi \& Arayici (2012) claimed that BIM implementation not only requires learning new software applications, but also learning how to reinvent the workflow, how to train staff and assign responsibilities, and the skill in modelling the projects. In the context of PPP, the risks are more severe because the data management has to be sustained for 20-40 years. Two more risks factors which are 'lack of guidelines for contractual agreements' and 'liability issues' are related to legal and contractual matters; thus, contractual risks related to collaborative and integrated working (Winfield, 2015, King's College Centre of Construction Law and Dispute Resolution, 2016) need to be addressed in order to eliminate the constraint that hinders having successful PPP projects implementing BIM.

\section{CONCLUSION}

PPP and BIM are well-promoted worldwide, and both can be integrated to boost the industry, however studies that integrate these two are very limited. The findings of the present study suggest that despite the massive benefits that BIM can offer to PPP projects, additional risks associated with BIM cannot be underrated. Risks related to technical competencies, social and legal are the most significant risks that can impact PPP projects, thus need to be addressed brilliantly to ensure success. Besides of adding to the limited knowledge in this field, the findings are considered as a lesson learnt for the Malaysian construction industry to consider developing relational-collaborative contractual instruments that can seamlessly integrate parties in PPP projects and acts as risks mitigating strategy in PPP projects implementing BIM.

\section{ACKNOWLEDGEMENTS}

The authors would like to express their sincere gratitude to Ministry of Higher Education Malaysia for providing the financial support for this paper to be published. This paper was funded under the grant of Fundamental Research Grant (FRGS/1/2019/TK06/UIAM/02/1).

\section{REFERENCES}

Abdul Rashid, K. (2007). Private Finance Initiative: Concept and Method of Procurement for Construction Projects with specific reference to Malaysia. Inreach Edition: Kuala Lumpur. 
Asenova, D., \& Beck, M. (2009). Obstacles to accountability in PFI projects. In A. Akintoye \& M. Beck (Eds.), Policy, finance \& management for Public Private Partnership (pp. 47-63). Oxford, UK: Blackwell.

Akerele, D., \& Gidado, K. (2003). The risks and constraints in the implementation of PFI/PPP in Nigeria. Paper presented at the 19th Annual Association of Researchers in Construction Management (ARCOM) Conference, University of Brighton, Brighton, UK. Retrieved from http://www.arcom.ac.uk/docs/proceedings/ar2003-379-391_Akerele_and_Gidado.pdf

Akintoye, A., Taylor, C., \& Fitzgerald, E. (1998). Risk analysis and management of private finance initiative projects. Engineering, Construction and Architectural Management, 5(1), 9-21.

Arayici, Y., Egbu, C.O. \& Coates, P. (2012). Building information modelling (BIM) implementation and remote construction projects: issues, challenges, and critiques. Journal of Information Technology in Construction, 17, 75-92.

Athias, L., \& Saussier, S. (2010). Contractual flexibility or rigidity for Publis Private Partnerships? Theory and evidence from infrastructure concession contracts. (Discussion paper series). Retrieved from http://www.webssa.net/ files/images /Athias-Saussier-2010.pdf

Azhar, S., Hein, M., \& Sketo, B. (2008). Building Information Modeling (BIM): Benefits, risks and challenges. Paper presented at the 44th ASC National Conference. Retrieved from http://ascpro.ascweb.org/chair/paper/CPGT182002008.pdf

Azhar, S., Khalfan, M., \& Maqsood, T. (2012). Building Information Modelling (BIM) Now and beyond. Australasian Journal of Construction Economics and Building, $12(4), 15-28$.

Bank Negara Malaysia (BNM). (2019a). Bank Negara Annual Report 2019. Retrieved from https://www.bnm.gov.my/index.php?ch=en_publication\&pub=ararc

Bank Negara Malaysia (BNM). (2019b). Budget 2020 Speech. Retrieved from https://www.bnm.gov.my/documents/budget/bs2020.pdf

Boyes, H. (2014). Building Information Modelling (BIM): Addressing the cyber security issues. London, UK: Institution of Engineering and Technology.

BuildingSMART. (2010). Investing in BIM Competence: A guide to collaborative working for project owners and building professionals. Retrieved from http://constructioncode.blogspot.co.uk/2010/10/buildingsmart-investing-inbim.html

Chien, K.-F., Wu, Z.-H., \& Huang, S.-C. (2014). Identifying and assessing critical risk factors for BIM projects: Empirical study. Automation in Construction, 45(2014), $1-15$.

Chinyio, E., \& Gameson, R. (2009). Private Finance Initiative in use. In A. Akintoye \& M. Beck (Eds.), Policy, finance and management for public private partnerships (pp. 3-26). Oxford: Blackwell.

CIDB. (2016). BIM Guide 1: Awareness. Retrieved from https://www.mybimcentre.com.my/download/bim-guide-book-/?wpdmdl=7520

Eaton, D., \& Akbiyikli, R. (2009). Innovation in PPP. In A. Akintoye \& M. Beck (Eds.), Policy, Finance, \& Management for Public-Private Partnership (pp. 303-326). Oxford, UK: Blackwell. 
Siti Nora Haryati Abdulllah Habib, Syuhaida Ismail, Sharifah Mazlina Syed Khuzzan,

Identification of Significant BIM Risk Factors for PPP Projects Implementing BIM in the UK: A Lesson

Learnt for Malaysia

Gamble, A. (1988). Privatization, Thatcherism and the British State. Journal of Law and Society, 16(1), 1-20.

Ganah, A., \& John, G.A. (2013). Suitability of BIM for enhancing value on PPP Projects for the benefit of the Public Sector. PPP International Conference 2013 Body of Knowledge, Preston, UK, 18-19 March, 2013.

Hardcastle, C., \& Boothroyd, K. (2008). Risks overview in Public-Private Partnership. In A. Akintoye, M. Beck \& C. Hardcastle (Eds.), Public-Private Partnerships: Managing Risks and Opportunities (pp. 31-57). Oxford, UK: Blackwell Publishing Ltd. Retrieved from http://onlinelibrary.wiley.com /doi/10.1002/9780470690703.ch2/pdf.

Harty, C., Throssell, D., Jeffrey, H., \& Stagg, M. (2010). Implementing building information modeling: a case study of the Barts and the London hospitals.

Retrieved from http://www.engineering.nottingham.ac.uk/icccbe/proceedings/pdf/pf93.pdf

Hodge, G.A., \& Greve, C. (2007). Public-private partnerships: An international performance review. Public Administration Review, 67(3), 545-558.

Ismail, S., \& Harris, F.A. (2014). Challenges in implementing public private partnership (PPP) in Malaysia. Procedia - Social and Behavioral Sciences, 164 (2014),5-10.

Khanom, N.A. (2010). Conceptual issues in defining public private partnerships (PPPs). International Review of Business Research Papers, 6(2), 150-163.

Khosrowshahi, F., \& Arayici, Y. (2012). Roadmap for implementation of BIM in the UK construction industry. Engineering, Construction and Architectural Management, 19(6), 610-635.

King's College London. (2016). Enabling BIM through procurement and contract. A Research Report by the Centre of Construction Law and Dispute Resolution, King's College London. Retrieved from https://www.kcl.ac.uk/law/research/centres/construction/enabling-bim/ ebimtpacform.aspx

Laishram, B. (2013). Building information modeling in Public Private Partnership Projects-perspectives and hurdles. Retrieved from http://dl.lib.mrt.ac.lk/handle/123/9507

Lehtinen, T. (2012). Increasing integration in construction projects: A case study on a PPP project adopting BIM. In G. Gudnason \& R. Scherer (Eds.), eWork and eBusiness in Architecture, Engineering and Construction 2012 (439-446). London: Taylor \& Francis.

Li, B., Akintoye, A., Edwards, P.J., \& Hardcastle, C. (2005). The allocation of risk in PPP/PFI construction projects in the UK. International Journal of Project Management, 23(1), 25-35.

Lindblad, H., \& Vass, S. (2015). BIM implementation and organisational change: A case study of a large swedish public client. Procedia Economics and Finance, 21(2015), 178-184.

Ness, A. (2011, 10 October). Managing the risk of BIM. Owners Perspective. Retrieved 15 March, 2015, from http://ownersperspective.org/managing-the-risks-of-bim/ 
Pollock, A.M., \& Price, D. (2008). Has the NAO audited risk transfer in operational private finance initiative schemes? Public Money and Management, 28(3), 173178.

Pollock, A.M., Price, D., \& Player, S. (2007). An examination of the UK Treasury's evidence base for cost and time overrun data in UK value-for-money policy and appraisal. Public Money and Management, 27(2), 127-134.

Quinn, A. (2014). Asset modelling to curb PFI Disputes? Retrieved from http://www.clydeco.com/insight/updates/view/asset-modelling-to-curb-pfidisputes.

Ren, G., \& Li, H. (2017). BIM Based Value for Money Assessment in Public-Private Partnership. 18th IFIP WG 5.5 Working Conference on Virtual Enterprises, PRO-VE 2017, Vicenza, Italy, September 18-20, 2017.

Shaoul, J. (2009). Using the Private Sector to Finance Capital Expenditure: The Financial Realities. In A. Akintoye \& M. Beck (Eds.), Policy, Finance and Management for Public Private Partnership (pp. 27-46). Oxford: Blackwell.

Simonian, L., \& Korman, T. (2010). Legal Considerations in the United States Associated with Building Information Modeling. Paper presented at the Construction, Building and Real Estate Research Conference of the Royal Institution of Chartered Surveyors (RICS COBRA 2010), Paris, France, 2nd - 3rd September, 2010.

Soomro, M.A., \& Zhang, X. (2015). Roles of Private-Sector Partners in Transportation Public-Private Partnership Failures. Journal of Management in Engineering, 4(31), http:// dx.doi.org/10.1061/(ASCE)ME.1943-5479.0000263

Sundaraj, G. (2012). Quantifying Robustness in PFI from the Perspectives of Granting Authority. (Unpublished $\mathrm{PhD}$ thesis), University of Salford, Salford.

Talebi, S. (2014). Exploring advantages and challenges of adaptation and implementation of BIM in project life cycle. Paper presented at the 2nd BIM International Conference on Challenges to Overcome, Portugal. Retrieved from http://usir.salford.ac.uk/32275/

Winfield, M. (2015a). Building Information Modelling: The legal frontier-Overcoming legal and contractual obstacles. Retrieved from http://www.scl.org.uk/papers/building-information-modelling-legal-frontierovercoming-legal-and-contractual-obstacles.

Received: $15^{\text {th }}$ May 2020. Accepted: $1^{\text {st }}$ Sept 2020 